\title{
Econometric Analysis of the Mortgage Loans Dependence on Per Capita Income
}

\author{
Samerkhanova A. A. ${ }^{1} \&$ Kadochnikova E. I. ${ }^{2}$ \\ ${ }^{1}$ Institute of Management, Economics and Finance, Kazan Federal University, Kazan, Russia \\ Correspondence: Samerkhanova A. A., Institute of Management, Economics and Finance, Kazan Federal \\ University, Kazan, 420008, Russia.
}

Received: December 27, 2014 Accepted: February 19, 2015 Online Published: April 30, 2015

doi:10.5539/ass.v11n11p55 URL: http://dx.doi.org/10.5539/ass.v11n11p55

\begin{abstract}
The article makes the econometric modeling of the size of the mortgage loan in order to identify the most important prognostic factors. The leading role of mortgage lending in the domestic banking services market is emphasized. Using Excel, Gretl software the authors are trying to prove the predominant influence of household income on the dynamics of the mortgage market. The article presents the methodical approach to measuring the dependence of mortgage loans on per-capita income. The results of empirical evaluations have confirmed their practical feasibility in the management of the credit portfolio.
\end{abstract}

Keywords: mortgage lending, per capita income, least square method, nonlinear regression, heteroscedasticity

\section{Introduction}

Currently, when there is instability of exchange rates, households are actively investing in real estate, the prices have always been increasing for it, and given the decline in national currency, it is advantageous for borrowers to capture their costs for the mortgage (Diaz-Serrano \& Raya, 2014; Lou \& Yin, 2014). For banks, the mortgage is a highly profitable product with a low degree of risk, so they continue to increase the share of mortgage loans in their portfolios (Ferreira, Spahr, \& Irina, 2013; Grydaki \& Bezemer, 2013). Therefore, it is possible to emphasize that mortgage lending in Russia is an important component of both the banking system and the economy as a whole. The state support of mortgage lending contributes to this, which, through the economic effects of increased consumption and increased demand leads to economic growth (Abel \& Bernanke, 2010; Jordi, 2008; Steinbuks \& Elliehausen, 2014). Even with unemployment and low income, employed population prefers to invest in property (Gabriel \& Rosenthal, 2013; Gyourko \& Tracy, 2014). In this regard, we have studied the dependence of the average size of mortgage credits on per-capita income of the population in the Russian Federation and the Volga Federal district in particular. Thus, the growing role of mortgage lending for the development of the national economy certainly testifies to the relevance of this article.

\section{Methods}

The study uses time series data from official site of the Central Bank of the Russian Federation and the Federal service of state statistics (Official website of the Federal service of state statistics; Official website of the Central Bank of the Russian Federation): the sample of 51 monthly observations for the period from the 1st quarter 2010 to the 1st quarter 2014 on the average amount of mortgage and average per capita money income in the Russian Federation as a whole, as well as the sample of 48 monthly observations for the period from 2010 to 2013 on the average amount of mortgage lending and average per capita money income in the Volga Federal district. Average loan size per month in rubles $(\mathrm{Y})$ and average per capita income $(\mathrm{X})$ were used as variables. In the study, we used the classical least square method and the weighted least squares method using the Gretl 1.9.91 software.

\section{Results}

The time series is significantly different from the simple sample data so that the analysis takes into account the correlation of measurements over time, and not just statistical diversity and statistical characteristics of the sample. When analyzing time series there can be two main objectives: characterization of the series nature (distinguishing deterministic and random components, their parameters estimation) and the use of the estimates received for forecasting (Hamilton, 1994). Based on time series, OLS-regression estimates (Wooldridge, 2013) of the average mortgage size per month depending on per capita income were obtained for the Russian Federation as a whole, and they are presented in Figure 1. 


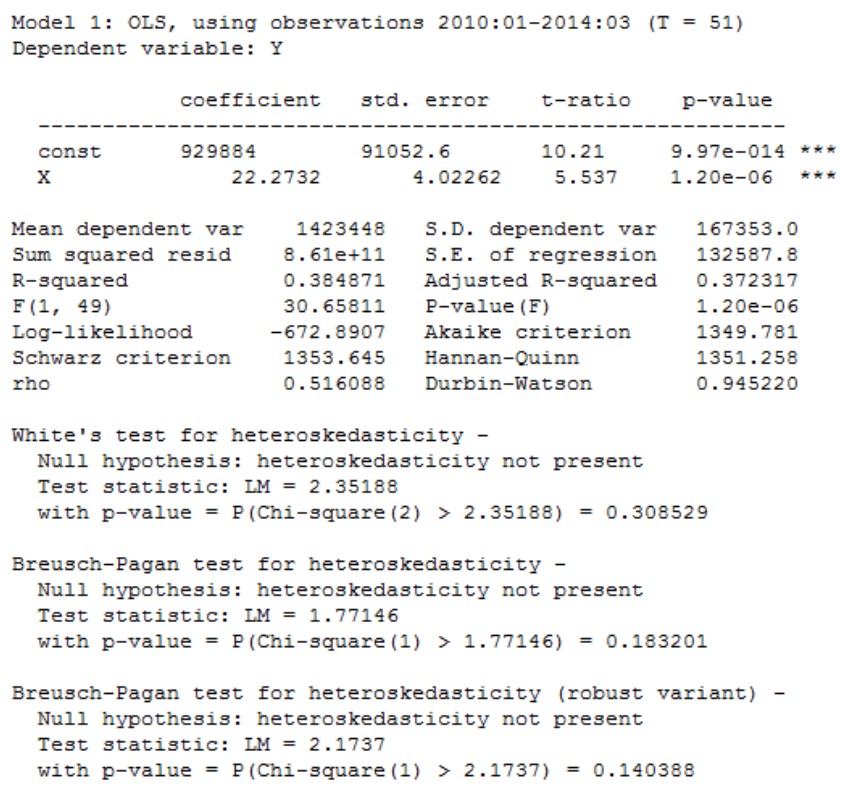

Figure 1. OLS-estimates of model of average mortgage lending in the Russian Federation as a whole

It is obvious that the linear regression model can be represented as: $\mathrm{Y}=929884+22.2732 * \mathrm{X}+\varepsilon$. Tests by White, Breusch-Pagan and robust version by Breusch-Pagan allow us to accept the null hypothesis of no heteroskedasticity in the residual of the regression. Each of the regression parameters and the overall model are statistically significant. Taking into account that the model explains $38 \%$ of the variation of the average mortgage size of, to improve the accuracy of the model we will apply a non-linear regression (Table 1), which shows that the most accurate is the power model.

Table 1. The simulation results of the average mortgage size in the Russian Federation

\begin{tabular}{ccc}
\hline Model type & Specification model & Standard error of the model \\
\hline Linear & $\mathrm{Y}=929884+22.2732 * \mathrm{X}+\varepsilon$ & 132587,8 \\
Power & $\mathrm{Y}=26664.81 * \mathrm{X}^{0.3976 * \varepsilon}$ & 0,09 \\
Exponential & $\mathrm{Y}=1039390 * \mathrm{e}^{0.000014 *} * \varepsilon$ & 134979,4 \\
Semi- $\log$ & $\mathrm{Y}=-4150170+558128 * \ln \mathrm{X}+\varepsilon$ & 127232,5 \\
\hline
\end{tabular}

The Volga Federal district is a most densely populated and prosperous federal districts in the Central Russia. Therefore, it is of interest to study mortgage lending in the district in comparison with the Russian Federation as a whole. OLS-regression estimates of the average mortgage size per month depending on per capita income in the Volga Federal district are presented in Figure 2.

As it can be seen from Figure 2, the linear regression model $Y=557450+25.6732 * X+\varepsilon$ is statistically significant. The model explains $48 \%$ of the variation of the average mortgage size, and the standard error of the model is 104244.9 rubles $(10 \%$ of the mean value of the dependent variable). The test by White does not confirm heteroscedasticity in the regression residuals when $\mathrm{p}$ value $=0.130(\mathrm{p}>0.05)$. In the test by Breusch-Pagan at the $\mathrm{p}=0.023(\mathrm{p}<0.05)$ heteroscedasticity was detected. A robust version of the test by Breusch-Pagan did not find the heteroscedasticity at the $\mathrm{p}=0.0604(\mathrm{p}>0.05)$.

To improve the quality of the model we will perform correction for heteroscedasticity of regression residuals using the weighted least squares method (Figure 3).

As can be seen from Figure 3, the tests by White, Breusch-Pagan and robust version by Breusch-Pagan allow us to accept the null hypothesis of no heteroskedasticity in the residuals of the regression. As the linear regression model: $\mathrm{Y}=556801+25.6922 * \mathrm{X}+\varepsilon$, and its parameters are statistically significant. The model explains $58 \%$ of the variation of the average mortgage size, and the standard error of the model is 5.411 rubles $(9 \%$ of the mean value of the dependent variable). Before correction the standard errors were $\mathrm{m}_{\mathrm{a}}=74047.2 ; \mathrm{m}_{\mathrm{b}}=3.8947$ (Figure 2), after correction they are: $\mathrm{m}_{\mathrm{a}}=70417.2 ; \mathrm{m}_{\mathrm{b}}=4.0138$ (Figure 3). The standard error decreased only for the coefficient a. 
The results of the correction for heteroscedasticity of regression residuals using built-in Gretl tools are presented in Figure 4.

The linear regression model $\mathrm{Y}=550802+26.0134 * \mathrm{X}+\varepsilon$ and its parameters are statistically significant. The model explains $48 \%$ of the variation of the average mortgage size, and the standard error of the model is 1.76 ruble. Before correction the standard errors were $\mathrm{m}_{\mathrm{a}}=74047.2 ; \mathrm{m}_{\mathrm{b}}=3.8947$ (Figure 2). After correction they are: $\mathrm{m}_{\mathrm{a}}=71540.6 ; \mathrm{m}_{\mathrm{b}}=3.9639$ (Figure 4). The standard error decreased only for the coefficient $\mathrm{a}$.

As it can be seen from Figure 5, the linear regression model $\mathrm{Y}=549542+26.098 * \mathrm{X}+\varepsilon$ and its parameters are statistically significant. The model explains $48 \%$ of the variation of the average size of the mortgage, and the standard error of the model is 743.347 ruble. The standard error for the free coefficient decreased: ma $=72467.4$; $\mathrm{mb}=3.9715$. Simulation results are evaluated in Table 2 .

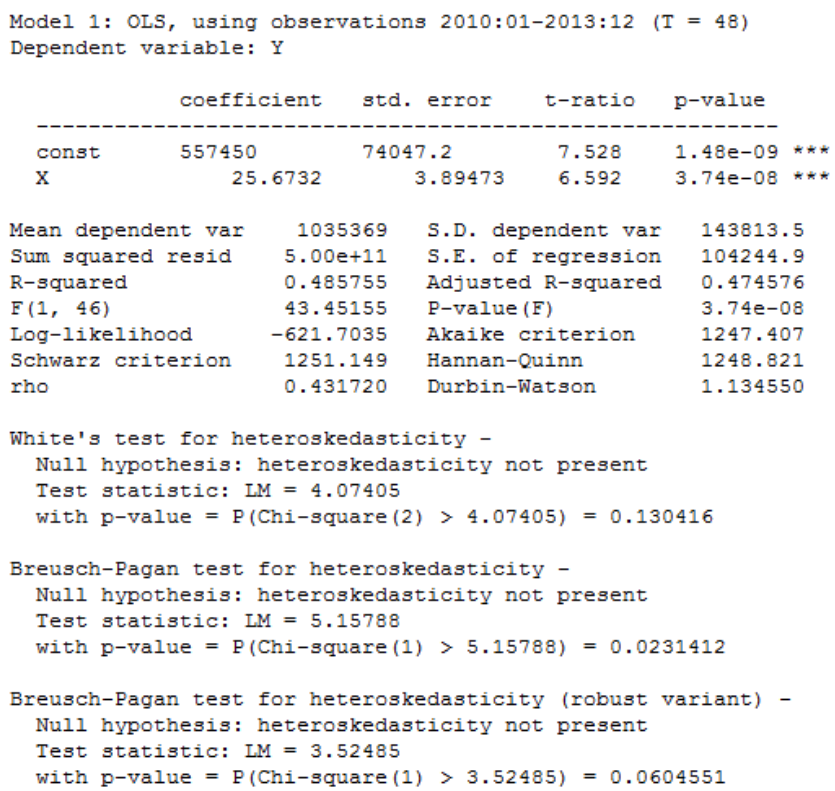

Figure 2. OLS-regression estimates of the average mortgage size per month depending on per capita income in the Volga Federal district

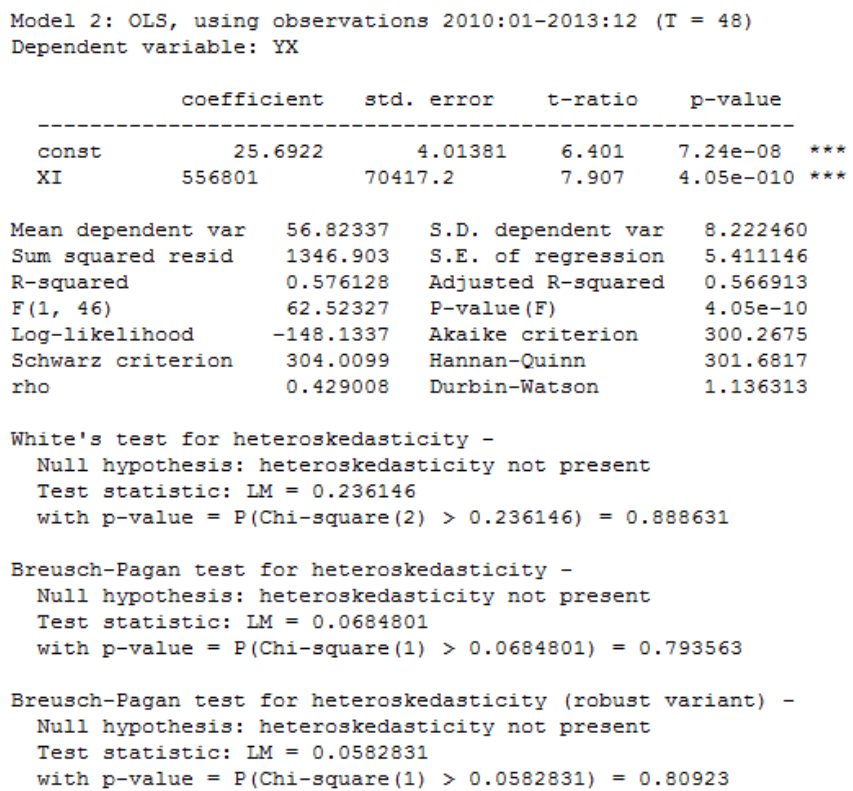

Figure 3. The model estimates of the average mortgage lending in the Volga Federal district obtained by the method of weighted least squares manually 


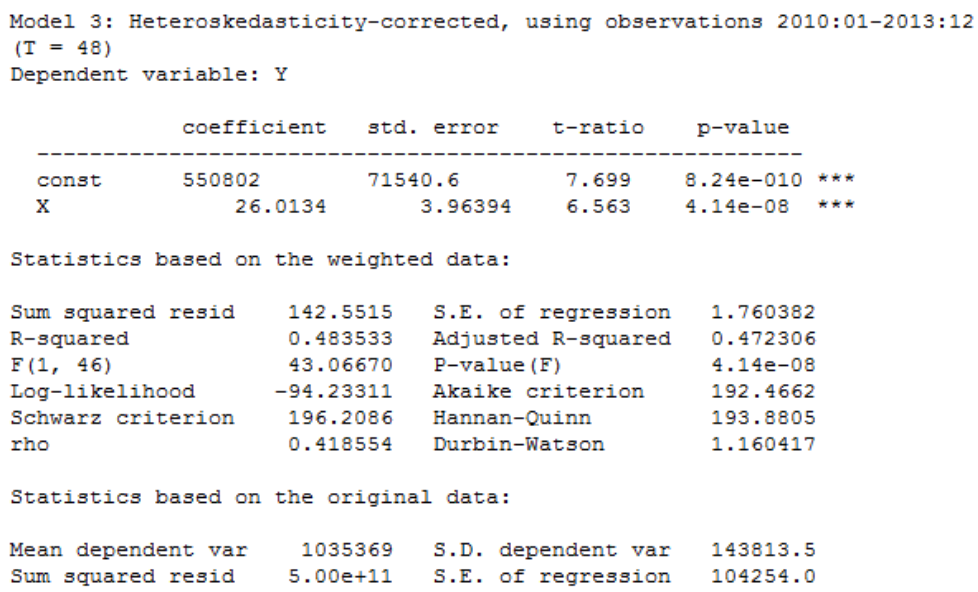

Figure 4. The model estimates of the average mortgage lending in the Volga Federal district received by means of Gretl

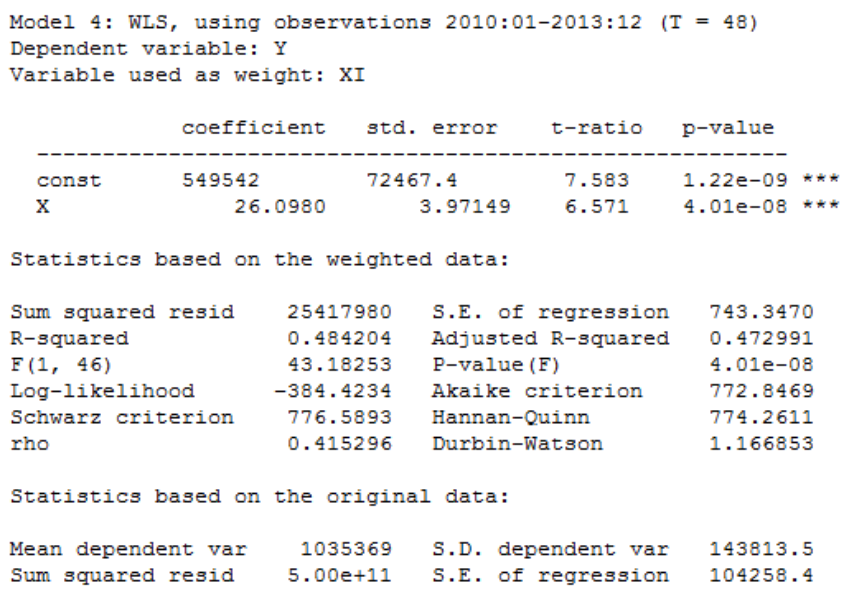

Figure 5. Model estimates of the average mortgage lending in the Volga Federal district, obtained by the method of weighted least squares of Gretl tools

According to the simulation results, with the increase of average money income per capita by 1 ruble, the average mortgage size for residents of the Russian Federation increased by 22.273 ruble, and for those of the Volga Federal district the increase is 25.763 rubles. Correction for heteroscedasticity helped to adjust the estimate of the regression coefficient to 26.013 rubles. Heteroscedasticity corrected model enabled to significantly reduce the sum of standard errors for the model in general and for the coefficients $a$ and $b$.

Table 2. Simulation results of the average mortgage size in the Volga Federal district

\begin{tabular}{ccccc}
\hline Equation type & Equation form & $\begin{array}{c}\text { Standard error of } \\
\text { the coefficient a }\end{array}$ & $\begin{array}{c}\text { Standard error of } \\
\text { the coefficient b }\end{array}$ & $\begin{array}{c}\text { Standard error } \\
\text { of the model }\end{array}$ \\
\hline $\begin{array}{c}\text { Linear regression } \\
\text { equation }\end{array}$ & $\mathrm{Y}=557450+25.7632 \mathrm{X}+\varepsilon$ & 74047.2 & 3.89473 & 104244.9 \\
$\begin{array}{c}\text { Weighted OLS } \\
\text { (manually) }\end{array}$ & $\mathrm{Y}=556801+25.6922 \mathrm{X}+\varepsilon$ & 70417.2 & 4.01381 & 5.4111 \\
$\begin{array}{c}\text { Heteroskedasticity } \\
\text { corrected }\end{array}$ & $\mathrm{Y}=550802+26.0134 \mathrm{X}+\varepsilon$ & 71540.6 & 3.96394 & 1.760382 \\
$\begin{array}{c}\text { Weighted OLS } \\
\text { (Gretl) }\end{array}$ & $\mathrm{Y}=549542+26.098 \mathrm{X}+\varepsilon$ & 72467.4 & 3.97149 & 743.347 \\
\hline
\end{tabular}




\section{Conclusions}

The performed econometric analysis of the dependence of the average mortgage size for a month on cash income per capita in the Russian Federation showed that the regression residuals are homoscedastic, which indicates the relative stability of mortgage lending dynamics.

During the research it was decided to construct a model of the average mortgage size for the Volga Federal district. Based on the analysis, we can draw the following practice-oriented conclusions:

1. The average amount of mortgage is growing with the growth of incomes more progressively. Direct correlation of mortgage lending with the growth in real income is seen, i.e., the faster household incomes are growing, the more opportunities there are to make savings to service the mortgage loan. This leads to the growth of the mortgage volume.

2. It is evident that one of the main factors in the development of the mortgage market in the Russian Federation is the growth of household income as a source of savings which is spent for housing purchase. With exchange rates instability, investing in real estate is more profitable than having deposits in banks.

Thus, the study confirmed the direct correlation between the growth of mortgage lending and wage growth. This model can be used for calculating future amounts of mortgage loans, forecasting growth or absence of demand in the mortgage market.

\section{References}

Abel, A., \& Bernanke, B. (2010). Macroeconomics (5th ed., p. 764). Addison Wesley.

Diaz-Serrano, L., \& Raya, J. M. (2014). Mortgages, immigrants and discrimination: An analysis of the interest rates in Spain. Regional Science and Urban Economics, (45), 22-32.

Ferreira, F. A. F., Spahr, R. W., \& Irina, F. M. D. (2013). Gavancha, Amali Çipi. Readjusting trade-offs among criteria in internal ratings of credit-scoring: an empirical essay of risk analysis in mortgage loans. Journal of Business Economics and Management, 14(4), 715-740.

Gabriel, S. A., \& Rosenthal, S. S. (2013). Urbanization, agglomeration economies, and access to mortgage credit. Regional Science and Urban Economics, (43), 42-50.

Grydaki, M., \& Bezemer, D. (2013). The role of credit in the Great Moderation: A multivariate GARCH approach. Journal of Banking \& Finance, (37), 4615-4626.

Gyourko, J., \& Tracy, J. (2014). Reconciling theory and empirics on the role of unemployment in mortgage default. Journal of Urban Economics, (80), 87-96.

Hamilton, J. D. (1994). Time Series Analysis (1st ed., p. 820). Princeton University Press.

Jordi, G. (2008). Monetary policy, inflation, and the business cycle: an introduction to the New Keynesian framework (p. 203). Princeton University Press.

Lou, W., \& Yin, X. (2014). The impact of the global financial crisis on mortgage pricing and credit supply. Journal of International Financial Markets, Institutions \& Money, (29), 336-363

Official website of the Central Bank of the Russian Federation. Retrieved from http://www.cbr.ru/ statistics/?Prtid=ipoteka

Official website of the Federal service of state statistics. Retrieved from http://www.gks.ru/free_doc/new_site/ population/urov/urov_11sub09-13.xls

Steinbuks, J., \& Elliehausen, G. (2014). The Economic Effects of Legal Restrictions on High-Cost Mortgages. The Journal of Real Estate Finance and Economics, 49, 47-72.

Wooldridge, J. (2013). Introductory Econometrics. A modern approach (5th ed., p. 909). J. Wooldridge. Michigan State University: South-Western Cengage Learning.

\section{Copyrights}

Copyright for this article is retained by the author(s), with first publication rights granted to the journal.

This is an open-access article distributed under the terms and conditions of the Creative Commons Attribution license (http://creativecommons.org/licenses/by/3.0/). 